\title{
SEGETAL SPECIES IN PLANT COMMUNITIES OF ENVIRONMENTAL ISLANDS IN AN AGRICULTURAL LANDSCAPE IN GREATER POLAND
}

\author{
KLARZYŃSKA, A. ${ }^{*}-$ KRYSZAK, A. $^{1}-$ MAĆKOWIAK, $Ł .{ }^{2}$ \\ ${ }^{1}$ Department of Grasslands and Natural Landscape, Poznan University of Life Sciences, \\ Poznan, Poland \\ (e-mail: anna.kryszak@up.poznan.pl) \\ ${ }^{2}$ Department of Nature Conservation and Natura 2000 Areas, Regional Directorate for \\ Environmental Protection in Poznan, Poznan, Poland \\ (e-mail: lukasz.mackowiak.poznan@rdos.gov.pl) \\ *Corresponding author \\ e-mail: agnieszka.klarzynska@up.poznan.pl \\ (Received $8^{\text {th }}$ Nov 2019; accepted $12^{\text {th }}$ Feb 2020)
}

\begin{abstract}
The aim of the research conducted in the years 2013-2018 in the Greater Poland region of Poland was to acquire knowledge about segetal plants representing the Stellarietea mediae class, which appears in the agricultural landscape of environmental islands, and also to determine the reason for its variability both in terms of habitat and connected with the type of agricultural utilization in neighbouring areas. In the areas from 5 to $50 \mathrm{~m}^{2}, 116$ phytosociological releves were taken using the classic BraunBlanquet's method, and these were then subjected to multilateral analysis. Species from Stellarietea mediae definitely dominate in the phytocenoses of inter-field balks (37 taxons), where they reach high stages of constancy. They were encountered less often among inter-field afforestations. In inter-field balks and inter-field waterhole banks species from Centauretalia cyani dominate among grain tillage, whereas ones from Polygono-Chenopodietalia are predominant in cornfields. Where live form structure is concerned, inter-fields balks are dominated by annual plants, whereas on the banks on inter-field waterholes and afforestations, the dominant forms are hemicrytophytes. In balks and afforestations almost $100 \%$ of species are synanthropic (mainly aprophytes and archaeophytes) and inter-field waterhole banks are dominated by native flora. The results show that variability in the species structure of marginal habitats in the agricultural landscape depends strictly on the type of tillage and utilization of neighbouring areas, as well as on soil and ecological conditions.

Keywords: biodiversity, segetal species, agriculture areas, balks, slopes of inter-field waterholes, interfield afforestations
\end{abstract}

\section{Introduction}

The significance of agricultural terrains in the protection of biodiversity is noticed more and more often (Symonides, 2010; Bjelajac et al., 2014; Dias Tavares et al., 2019). Observing the results of the deformation of the natural environment in agricultural areas caused by human activities aimed at obtaining food for people and fodder for animals, attention has been drawn to the surfaces of the elements of natural landscape structure - the so-called 'ecological margins' - still characterized by high biodiversity (Banaszak and Cierzeniak, 2002; Chappell and LaValle, 2011; Jacot et al., 2006; Karg, 2003; Loster, 1991; Ożgo, 2010). Such parts are microecosystems of the agricultural environment, i.e. inter-field afforestations, waterholes and balks. They function as environmental islands. These environmental islands are themselves act as support for biodiversity. They also help sustain the durability of the surrounding agroecosystems by being both a barrier to pollution and ecological corridors, and 
support for animals (Knapp and Řezáč, 2015; Morelli, 2013; Duelli and Obrist, 2003; Tscharntke et al., 2002). They are covered with typical flora, the retention of which is increasingly difficult, as it is endangered by agrotechnical pressure (Barrios et al., 2018; Fisher and Lindenmayer, 2007). A visible aspect which is a threat to their floral diversity is the simplification of agricultural landscape structure as a result of monoculturalization of tillage and the implementation of modern agrotechnical solutions (Kleps, 2009). On one hand, this leads to the extinction of groups of narrowly specialized organisms, and on the other, to the proliferation of organisms of which are often expansive and of a wide ecological scale (Afranowicz-Cieślak, 2011; Batáry et al., 2011; Kapeluszny and Haliniarz, 2010; Tokarska-Guzik et al., 2011). Owing to this, the appearance of common weeds, along with the simultaneous impoverishing of their population composition (Dąbrowska-Prot, 1984), is observed more and more often in phytocenoses formed in balks, inter-field afforestations, on the banks of inter-field waterholes.

The aim of the research was to identify flora covering what are termed 'environmental islands of the agricultural landscape' with a special analysis of segetal plants representing the Stellarietea mediae class. Furthermore, the reasons for the diversification of phytocenoses of ecological margins - both of the habitat and that which is dependent on the type of agricultural tillage of the directly adjacent areas were defined.

\section{Materials and methods}

Floristic research was conducted in Greater Poland region (Poland) (Fig. 1) in vegetative seasons (May, June and the beginning of July) from 2013 to 2018 (Figs. Al3 in the Appendix).

In areas ranging from 5 to $50 \mathrm{~m}^{2}, 116$ phytosociological relevés were taken using the Braun-Blanquet method (Table 1.).

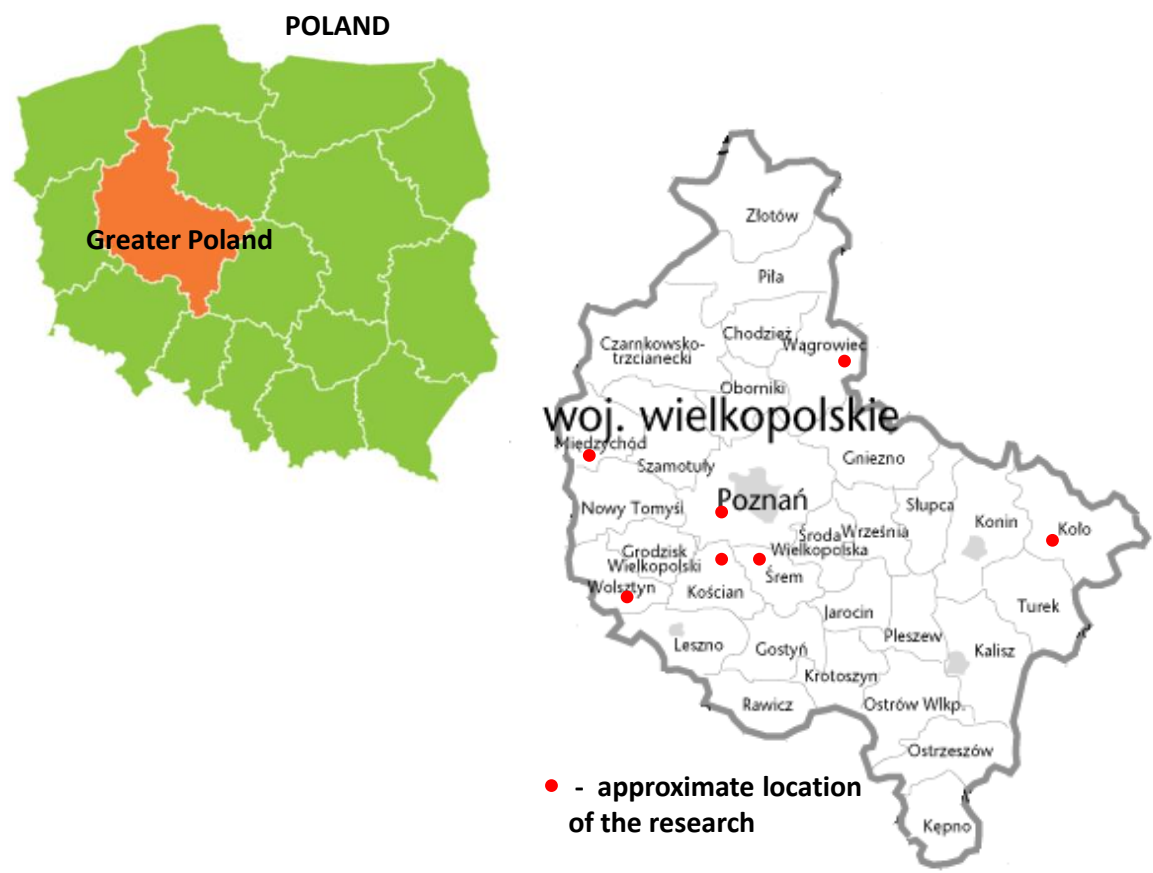

Figure 1. Location of the research 
Table 1. Research areas

\begin{tabular}{c|c|c}
\hline $\begin{array}{c}\text { Agrocoenoses adjacent with surfaces } \\
\text { of studied of environmental islands }\end{array}$ & & $\begin{array}{c}\text { Number of } \\
\text { phytosociological relevés }\end{array}$ \\
\hline Balks & Between tillages of maize and rape & 7 \\
1 & Between tillages of maize and cereals & 13 \\
2 & Between tillages of root crops and grain & 13 \\
3 & Between tillages of cereals & 16 \\
4 & Among tillage of cereals & 18 \\
\hline Slopes of inter-field waterholes & Among tillages of maize & 15 \\
5 & Bordering the tillage of cereals & 12 \\
6 & Bordering the tillage of maize & 11 \\
7 & Bordering the tillage of rape & 11 \\
\hline
\end{tabular}

Phytosociological relevés were saved in a database of the TURBOVEG program (Hennekens and Schaminée, 2001) and subsequently imported to the JUICE program (Tichý, 2002), with the assistance of which the initial hierarchical TWINSPAN classification analysis (Hill, 1979) was conducted. This analysis enabled them to be divided and gave an initial insight into the similarities and differences between the photos. The collection of 116 phytosociological relevés was also analyzed by means of the CANOCO 5.0 program (Braak and Šmilauer, 2014). First, NMDS (non-metric multidimensional scaling) analysis was conducted, which showed Euclidean distances between each releve. These distances are the ecological distance and corresponds with the differences in species composition between the samples (Kindt and Coe, 2005). Next, in order to obtain environmental gradients explained with floral data, PCA analysis results were presented.

Phytosociological structure (Matuszkiewicz, 2012) and botanical diversity were analyzed using classical methods, diversity was marked with Shannon-Wiener - H' rate (Magurran, 1996); the structure of life forms (Zarzycki et al., 2002), and the origin of flora (Jackowiak, 1990) were also marked and the stability of segetal species entering these habitats was defined.

Diversification of habitat conditions was defined with the phytoindication method (Ellenberg and Leuschner, 2010). Indicators such as: L - light conditions, F - habitat moisture, $\mathrm{R}$ - soil reaction, $\mathrm{N}$ - nitrogen content were considered.

\section{Results}

Among the environmental islands of the agricultural landscape analyzed, phytocenoses formed on the banks of inter-field waterholes are the richest in plant species. 127 plant species were found on their surfaces, whereas the fewest species among all the analyzed areas were found on the balks -74 taxons.

However, what influences the species richness of environmental islands in the agricultural landscape is not only their type but also the neighborhood of the agrocenoses. According to both the total number of species and the average number of species in the phytosociological relevé, more plant species were found in the phytocenoses bordering cereal tillage. On each environmental island in the areas bordering those tillages, an average of 15 species was observed in the phytosociological relevé. Slightly fewer species were found in the areas bordering corn tillage, whereas 
significantly fewer species were observed in the phytosociological relevés taken on environmental islands adjacent to rape and root crop tillages (Table 2).

Table 2. Floral diversification of environmental islands

\begin{tabular}{|c|c|c|c|c|c|c|c|}
\hline 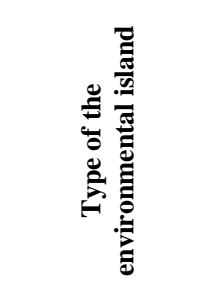 & 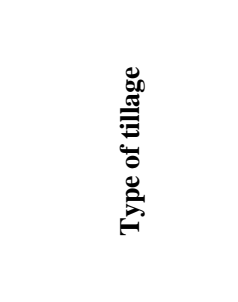 & 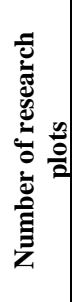 & 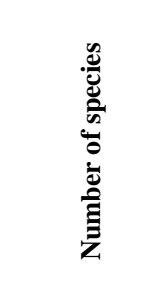 & 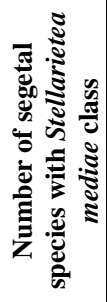 & 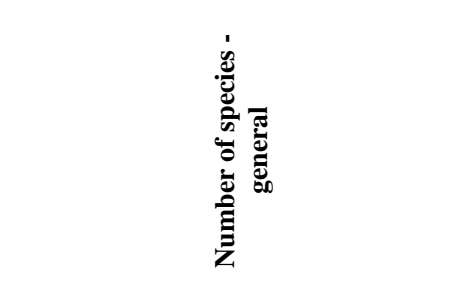 & 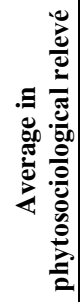 & $\overline{1}$ \\
\hline Balks & $\begin{array}{c}\text { Cereals - cereals } \\
\text { Maize - cereals } \\
\text { Root crops - cereals } \\
\text { Maize - rape } \\
\end{array}$ & $\begin{array}{c}16 \\
13 \\
13 \\
7 \\
\end{array}$ & $\begin{array}{l}47 \\
48 \\
35 \\
13 \\
\end{array}$ & $\begin{array}{c}27 \\
25 \\
16 \\
8 \\
\end{array}$ & 74 & $\begin{array}{c}14.9 \\
10.8 \\
8.0 \\
6.6 \\
\end{array}$ & $\begin{array}{l}1.70 \\
1.48 \\
1.16 \\
1.52 \\
\end{array}$ \\
\hline $\begin{array}{l}\text { Slopes of inter- } \\
\text { field waterholes }\end{array}$ & $\begin{array}{l}\text { Cereals } \\
\text { Maize }\end{array}$ & $\begin{array}{l}18 \\
15 \\
\end{array}$ & $\begin{array}{l}98 \\
85 \\
\end{array}$ & $\begin{array}{c}14 \\
9 \\
\end{array}$ & 127 & $\begin{array}{l}14.7 \\
13.0 \\
\end{array}$ & $\begin{array}{l}1.72 \\
1.56 \\
\end{array}$ \\
\hline $\begin{array}{l}\text { Inter-field } \\
\text { afforestations }\end{array}$ & $\begin{array}{c}\text { Cereals } \\
\text { Maize } \\
\text { Rape }\end{array}$ & $\begin{array}{l}12 \\
11 \\
11 \\
\end{array}$ & $\begin{array}{l}73+12 \text { (tree) } \\
68+10 \text { (tree) } \\
52+11 \text { (tree) }\end{array}$ & $\begin{array}{l}22 \\
21 \\
19 \\
\end{array}$ & 101 (herbaceous layer) + 19 (trees layer) & \begin{tabular}{l|}
14.6 \\
14.4 \\
11.7 \\
\end{tabular} & $\begin{array}{l}1.92 \\
1.98 \\
1.66 \\
\end{array}$ \\
\hline
\end{tabular}

The analysis of segetal species in the phytocenoses of environmental islands carried out on the basis of phytosociological structure showed their highest percentage on interfield balks (45-59\%) and a lower one in inter-field afforestations (29-39\%). Nevertheless, what draws attention on the banks of inter-field waterholes is the highest proportion of species characteristic of Molinio-Arrhenatheretea class (c. 40\%) with a very low proportion of species from the Stellarietea mediae class (Fig. 2). Moreover, on balks as well as on the banks of inter-field waterholes and afforestations, in general, the highest proportion in the total number of species is for taxons characteristic of the Stellarietea mediae class in the areas bordering grain tillage, while far fewer of these species were observed in the phytocenoses of environmental islands bordering corn and rape tillages.

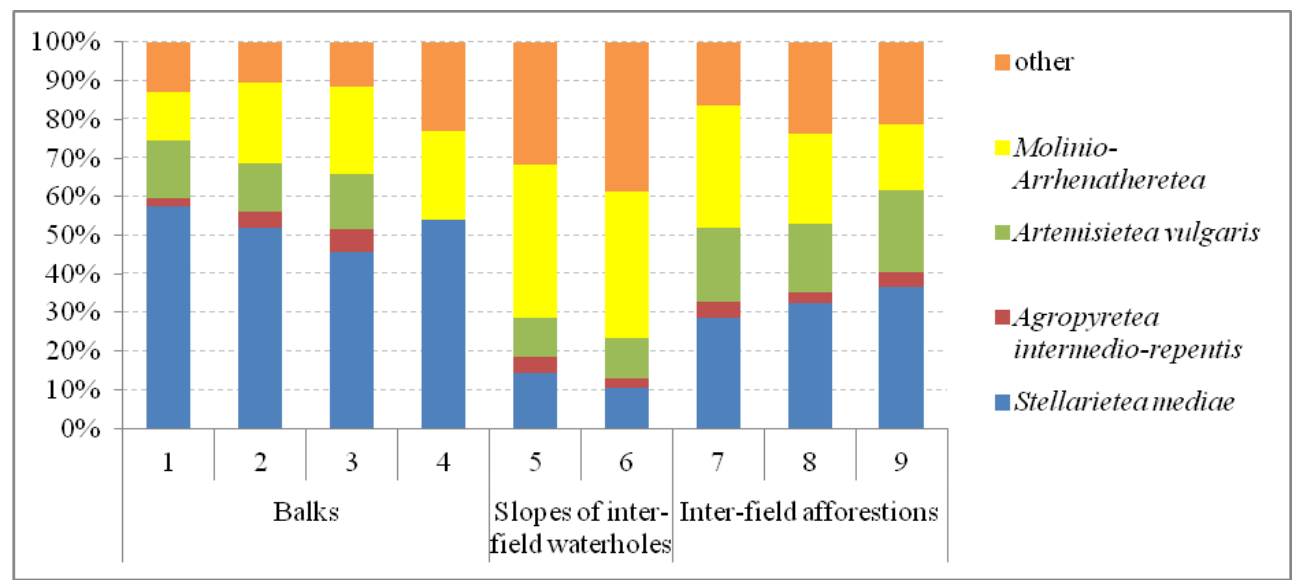

Figure 2. Phytosociological diversification of ecological margin flora. Explanations: Balks 1 between tillages of maize and rape; 2 - between tillages of maize and cereals; 3 - between tillages of root crops and grain; 4 - between tillages of cereals; Slopes of inter-field waterholes 5 - among tillage of cereals; 6 - among tillages of maize; Inter-field afforestations 7 - bordering the tillage of cereals; 8 - bordering the tillage of maize; 9 - bordering the tillage of rape 
What is particularly notable when analyzing the syntaxonomical diversification of the Stellarietea mediae class species is the high proportion of species characteristic of phytocenoses adjacent to cereal and flax tillages from Centauretalia cyani. Their particularly significant level was observed in balk phytocenoses (39-49\%). The growing influence of adjacent agrocenoses on the species composition of the phytocenoses of environmental islands is also proved by the highest degree of species characteristic of phytocenoses accompanying root species from Polygono-Chenopodietalia cultivated in fertile and semi-fertile soils when these areas were adjacent to rape tillage. By contrast, the species composition of afforestation undergrowth is often random, therefore the appearance of numerous species of annuals and biennials of ruderal areas in the first stadium of Sisymbrietalia succession was observed in the areas analyzed (Fig. 3).

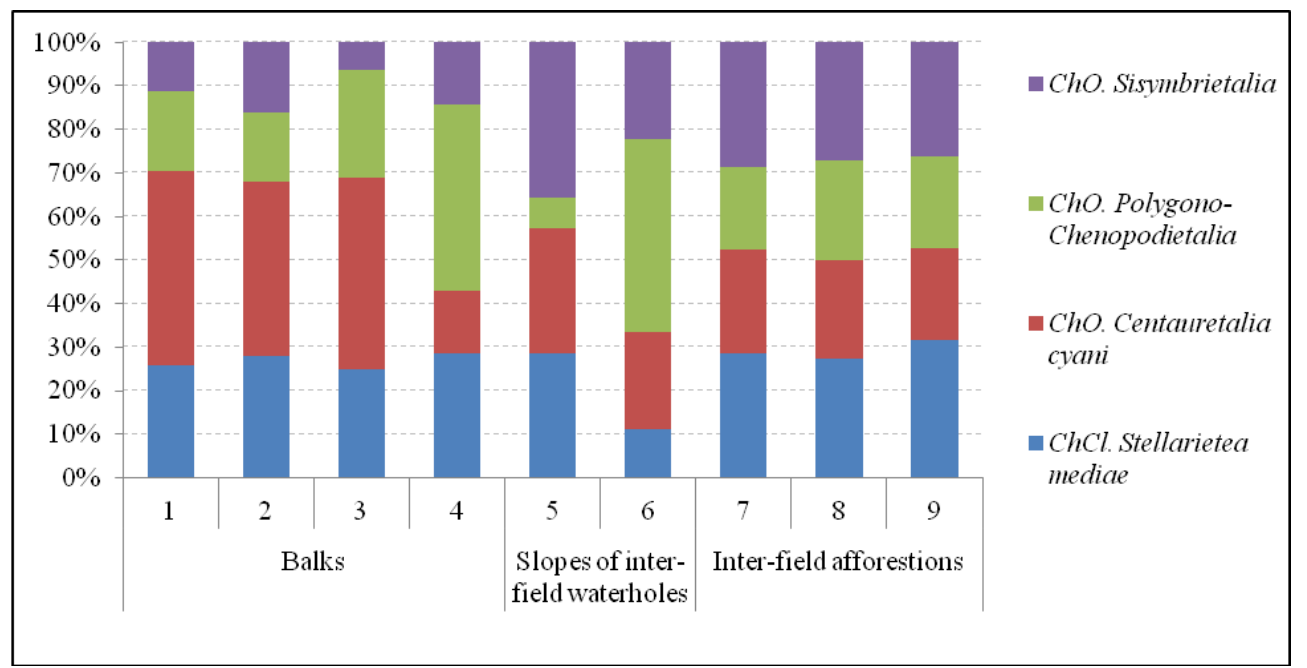

Figure 3. Diversification of Stellarietea mediae class. Explanations: Balks 1 - between tillages of maize and rape; 2 - between tillages of maize and cereals; 3 - between tillages of root crops and grain; 4 - between tillages of cereals; Slopes of inter-field waterholes 5 - among tillage of cereals; 6 - among tillages of maize; Inter-field afforestations 7 - bordering the tillage of cereals; 8 - bordering the tillage of maize; 9 - bordering the tillage of rape

Multidimensional scaling showed mainly that the value of the species cover coefficient from the Stellarietea mediae class determine the floral diversification of environmental islands (Fig. 4). Having taken into consideration axis X (59.97\% defined changeability), balk phytocenoses showed the highest coefficient of the coverage with the species, whereas on axis Y (20.83\% defined changeability), releves diffused due to the domination of taxons characteristic of those from the Stellarietea mediae class in floral composition.

Environmental islands undergo a strong influence from their surroundings and therefore do not develop stable abiotic and biotic conditions, which results in a high proportion of short-term species (terophytes) and synanthropic ones, among which species from the Stellarietea mediae class clearly predominate (from almost $80 \%$ to $100 \%$ ). The biggest share of terophytes was observed in balk phytocenoses (from more than $57 \%$ to $66 \%$ ). In the structure of species' live forms existing in inter-field afforestation and on waterholes' banks, the domination of hemicrytophytes was observed, yet terophytes were the second biggest group of plants in terms of number (from more than $17 \%$ to more than $42 \%$ ) (Table 3). 


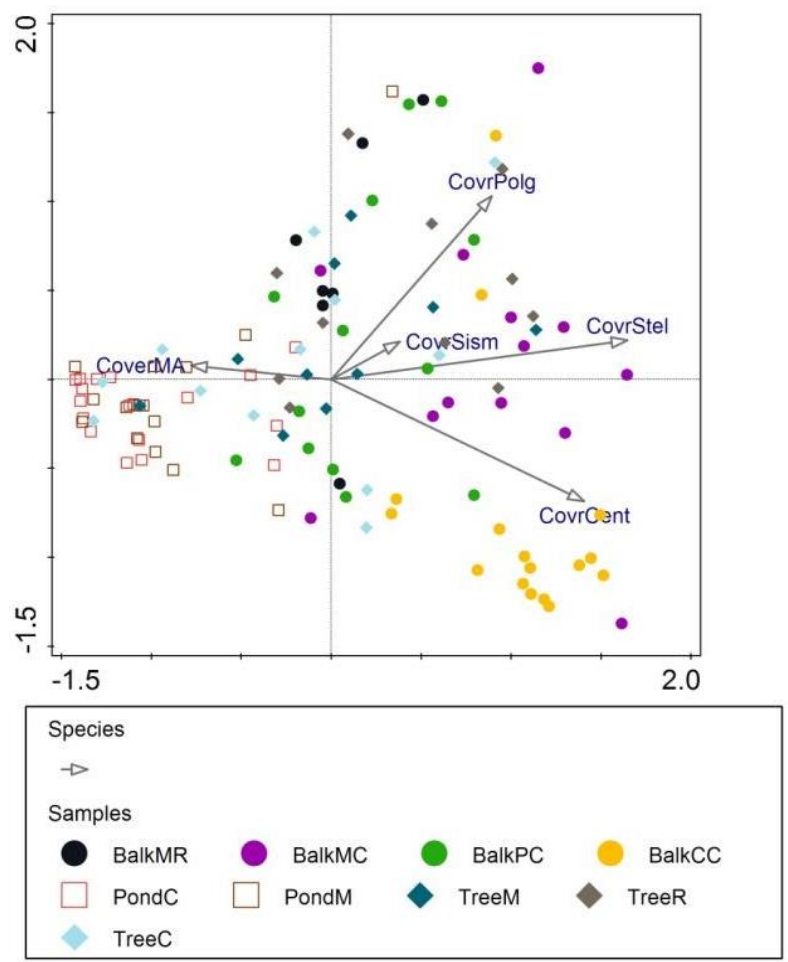

Figure 4. NMDS diagram of Euclidean distances between samples. Explanations: CoverMA cover by species from Mollinio-Arrhenatheretea Class; CoverStel - cover by species from Stellarietea mediae Class; CoverPolg - cover by species from Polygono-Chenopodietalia Order; CoverSism - cover by species from Sisymbrietalia Order; CoverCent - cover by species from Centauretalia cyani Order; BalkMR - balks between tillages of maize and rape; BalkMC balks between tillages of maize and cereals; BalkPC - balks between tillages of root crops and grain; BalkCC - balks between tillages of cereals; PondC - slopes of inter-field waterholes among tillage of cereals; PondM - slopes of inter-field waterholes among tillages of maize;

TreeM - inter-field afforestations bordering the tillage of maize; TreeR - inter-field afforestations bordering the tillage of rape; TreeC - inter-field afforestations bordering the tillage of cereals

In the general flora of the areas examined, the biggest proportion was represented by native species (from more than 50\% to almost 90\%) and among them synanthropic plants - apophytes. A particularly large number of native species, both apophytes and spontaneophytes, was found in the phytocenoses of inter-field waterhole banks. The majority of anthropophytes were archaeophytes - from more than 7\% to almost $45 \%-$ and the dominant group comprised species from the Stellarietea mediae class. A comparative analysis of archaeophytes appearing on the surfaces of environmental islands proved that they play the most important role in the phytocenoses of balks, especially those separating cereal tillages. However, the areas most resistant to the development of anthropophytes are the areas of waterhole banks (Table 3).

When analyzing the frequency of appearance of species characteristic of the Stellarietea mediae class in the phytocenoses of environmental islands, what draws attention is that the highest $-5^{\text {th }}$ and $6^{\text {th }}$ level of constancy in balks and inter-field afforestations was observed in Apera spica-venti, Chenopodium album and Viola arvensis. However, what was also identified on balks was very the frequent appearance of Centaurea jacea, Chamomilla recutita, Conyza canadensis, Viola arvensis, and 
frequent of Anchusa arvensis, Consolida regalis, Myosotis arvensis, Centaurea cyanus, Echinochloa crus-gali. However, no segetal species at the $5^{\text {th }}$ or $6^{\text {th }}$ level were noted on the phytocenoses of inter-field waterhole banks. Most of the segetal species on the banks are taxons rarely seen in phytosociological photos and therefore only reaching the $1^{\text {st }}$ or $2^{\text {nd }}$ level of constancy. Such a structure of constancy levels of waterhole banks species may prove the low constancy of developed phytocenoses which may be endangered by the appearance of common species and sometimes invasive ones from neighbouring phytocenoses. Furthermore, their instability may be associated with high moisture in the banks, which depends on the ground water level, and it often changes throughout the vegetation season. Segetal species present in the undergrowth of banks cannot cope with such fluctuations in moisture and therefore disappear, to be replaced by species with high adaptability to their surroundings and biological traits (Table 4). Among the segetal species observed, some are not harmful newcomers which take on the status of domesticated invasive plants and contribute to the loss of environmental islands' naturalness. These include Conyza canadensis, Echinochloa crus-gali and Veronica persica.

Table 3. Spectrum of live forms and geographic and historical ones of phytocenoses of the environmental islands analyzed

\begin{tabular}{|c|c|c|c|c|c|c|c|c|c|c|}
\hline \multirow{2}{*}{\multicolumn{2}{|c|}{ Type of use }} & \multicolumn{4}{|c|}{ Balks } & \multicolumn{2}{|c|}{$\begin{array}{l}\text { Slopes of inter- } \\
\text { field waterholes }\end{array}$} & \multicolumn{3}{|c|}{$\begin{array}{c}\text { Inter-field } \\
\text { afforestations }\end{array}$} \\
\hline & & $\begin{array}{c}\text { Cereals - } \\
\text { cereals }\end{array}$ & $\begin{array}{l}\text { Maize - } \\
\text { cereals }\end{array}$ & $\begin{array}{l}\text { Root crops - } \\
\text { cereals }\end{array}$ & $\begin{array}{c}\text { Maize - } \\
\text { rape }\end{array}$ & Cereals & Maize & Cereals & Maize & Rape \\
\hline \multicolumn{11}{|c|}{ Life form of species [\%] } \\
\hline $\mathrm{Ch}$ & Total & 8.5 & 4.2 & 2.9 & 7.7 & 6.1 & 3.5 & 2.7 & 5.9 & 3.8 \\
\hline \multirow{2}{*}{$\mathrm{G}$} & Total & 10.6 & 12.5 & 17.1 & 7.7 & 13.3 & 16.5 & 12.3 & 11.8 & 11.5 \\
\hline & Stel. med. & 3.7 & 0.0 & 0.0 & 0.0 & 7.1 & 0.0 & 4.8 & 0.0 & 5.3 \\
\hline \multirow{2}{*}{$\mathrm{H}$} & Total & 14.9 & 25.0 & 20.0 & 23.1 & 48.0 & 44.7 & 46.6 & 42.6 & 34.6 \\
\hline & Stel. med. & 3.7 & 12.0 & 0.0 & 12.5 & 14.3 & 0.0 & 4.8 & 9.1 & 10.5 \\
\hline $\mathrm{Hy}$ & Total & 0.0 & 0.0 & 0.0 & 0.0 & 8.2 & 10.6 & 0.0 & 0.0 & 0.0 \\
\hline $\mathrm{F}$ & Total & 0.0 & 0.0 & 2.9 & 0.0 & 7.1 & 4.7 & 4.1 & 4.4 & 7.7 \\
\hline \multirow[t]{2}{*}{$\mathrm{T}$} & Total & 66.0 & 58.3 & 57.1 & 61.5 & 17.3 & 20.0 & 34.2 & 35.3 & 42.3 \\
\hline & Stel. med. & 92.6 & 88.0 & 100.0 & 87.5 & 78.6 & 100.0 & 90.5 & 90.9 & 84.2 \\
\hline Sum & & 100 & 100 & 100 & 100 & 100 & 100 & 100 & 100 & 100 \\
\hline \multicolumn{11}{|c|}{ Geographical-historical spectrum of flora [\%] } \\
\hline \multirow{2}{*}{ Ap } & Total & 48.9 & 54.2 & 57.1 & 53.8 & 68.4 & 71.8 & 71.2 & 63.2 & 61.5 \\
\hline & Stel. med. & 29.6 & 32.0 & 25.0 & 37.5 & 35.7 & 11.1 & 19.0 & 18.2 & 26.3 \\
\hline \multirow{2}{*}{ Arch } & Total & 44.7 & 33.3 & 34.3 & 30.8 & 11.2 & 7.1 & 23.3 & 25.0 & 30.8 \\
\hline & Stel. med. & 66.7 & 52.0 & 62.5 & 37.5 & 57.1 & 55.6 & 71.4 & 68.2 & 68.4 \\
\hline \multirow{2}{*}{ Ee } & Total & 0.0 & 2.1 & 0.0 & 0.0 & 1.0 & 1.2 & 0.0 & 2.9 & 1.9 \\
\hline & Stel. med. & 0.0 & 4.0 & 0.0 & 0.0 & 0.0 & 11.1 & 0.0 & 9.1 & 5.3 \\
\hline \multirow{2}{*}{ Ken } & Total & 4.3 & 8.3 & 5.7 & 15.4 & 2.0 & 2.4 & 4.1 & 4.4 & 5.8 \\
\hline & Stel. med. & 3.7 & 12.0 & 12.5 & 25.0 & 7.1 & 22.2 & 9.5 & 4.5 & 0.0 \\
\hline $\mathrm{Sp}$ & Total & 2.1 & 2.1 & 2.9 & 0.0 & 17.3 & 17.6 & 1.4 & 4.4 & 0.0 \\
\hline Sum & & 100 & 100 & 100 & 100 & 100 & 100 & 100 & 100 & 100 \\
\hline
\end{tabular}

Ch - Chamephytes; G - Geophytes; H - Hemikryptophytes; F - Fanerophytes; T - Terophytes; Ap - Apophytes; Arch - Archeophytes; Ee - Epekophytes; Ken - Kenophytes; Sp - Spontaneophytes

The species composition of environmental island phytocenoses, including the appearance of segetal species, is strictly connected with habitat conditions. The most homogenous habitat conditions assessed with ecological coefficients in terms of light and moisture are balks, whereas the highest ecological amplitudes in terms of light are found in inter-field afforestation phytocenoses, and in terms of moisture and trophism, 
in inter-field waterhole banks. It may be assumed that a small number of species, including a major percentage of terophytes and species characteristic of cereal tillage phytocenoses from Centauretalia cyani observed on balks, may be connected with moisture conditions that show drying (the average value of $F$ coefficient - c. 5) and quite high firmness of the herbal layer, which creates the conditions for half-shadow (the average value of the L coefficient - c. 6.5). In the low and firm undergrowth of inter-field waterhole banks, light interception is better (the average value of light $\mathrm{L}$ coefficient - c. 6) in plants, at mild moisture (the average value of $\mathrm{F}$ coefficient almost 7) and habitat trophism (the average value of $\mathrm{N}$ coefficient $-\mathrm{c}$. 7). These are favorable conditions for the appearance of a high number of plant species, a higher share of hemicrytophytes and species characteristic for phytocenoses accompanying roots cultivated in fertile and semifertile soils, representing Polygono-Chenopodietalia. The species composition of inter-field afforestations mostly influences the shadowing of the herbal layer of undergrowth (the average value of $L$ coefficient - c. 6), when compound with moisture (the average value of F coefficient - more than 7) and high richness of soils in nitrogen (the average value of $\mathrm{N}$ coefficient - more than 6.6). Out of all the phytocenoses of environmental islands, it is characterized by the biggest proportion of Sisymbrietalia species (Fig. 5).

Table 4. Distribution of constancy levels of species observed in the phytocenoses of environmental islands

\begin{tabular}{|c|c|c|c|c|}
\hline \multirow{2}{*}{$\begin{array}{c}\text { Environmental } \\
\text { islands }\end{array}$} & \multirow{2}{*}{$\begin{array}{c}\text { Type of } \\
\text { tillage }\end{array}$} & \multicolumn{3}{|c|}{ Constancy } \\
\hline & & $\mathbf{V}$ & IV & III \\
\hline \multirow{4}{*}{ Balks } & $\begin{array}{l}\text { Cereals - } \\
\text { cereals }\end{array}$ & $\begin{array}{l}\text { Agropyron repens, } \\
\text { Apera spica-venti, } \\
\text { Centaurea jacea, } \\
\text { Chamomilla recutita, } \\
\text { Conyza canadensis, } \\
\text { Viola arvensis } \\
\end{array}$ & $\begin{array}{l}\text { Anchusa arvensis, } \\
\text { Chenopodium album, } \\
\text { Consolida regalis, } \\
\text { Myosotis arvensis }\end{array}$ & $\begin{array}{c}\text { Convolvulus arvensis, Fallopia } \\
\text { convolvulus, Papaver dubium, } \\
\text { Stellaria media }\end{array}$ \\
\hline & $\begin{array}{l}\text { Maize - } \\
\text { cereals }\end{array}$ & Apera spica-venti & $\begin{array}{l}\text { Agropyron repens, } \\
\text { Centaurea cyanus, } \\
\text { Echinochloa crus- } \\
\text { galli }\end{array}$ & $\begin{array}{l}\text { Anthoxanthum aristatum, } \\
\text { Galeopsis tetrachit, Polygonum } \\
\text { lapatifolium, Viola arvensis }\end{array}$ \\
\hline & $\begin{array}{l}\text { Root crops - } \\
\text { cereals }\end{array}$ & Agropyron repens & $\begin{array}{l}\text { Chenopodium album, } \\
\text { Viola arvensis } \\
\end{array}$ & $\begin{array}{l}\text { Centaurea cyanus, Chamomilla } \\
\text { recutita, Echinochloa crus-galli }\end{array}$ \\
\hline & Maize - rape & $\begin{array}{l}\text { Agropyron repens, } \\
\text { Artemisia campestris, } \\
\text { Chenopodium album } \\
\end{array}$ & & Galinsoga ciliata, Viola arvensis \\
\hline \multirow{2}{*}{$\begin{array}{l}\text { Slopes of inter- } \\
\text { field waterholes }\end{array}$} & Cereals & & & $\begin{array}{l}\text { Cirsium arvense, Galium aparine, } \\
\text { Galium palustre, Lyschimachia } \\
\text { nummularia, Urtica dioica, }\end{array}$ \\
\hline & Maize & & & $\begin{array}{c}\text { Lychnis flos-cuculi, Holcus } \\
\text { lanatus, Poa pratensis }\end{array}$ \\
\hline \multirow{3}{*}{$\begin{array}{l}\text { Inter-field } \\
\text { afforestations }\end{array}$} & Cereals & $\begin{array}{l}\text { Sambucus nigra, } \\
\text { Urtica dioica }\end{array}$ & Galium aparine & $\begin{array}{l}\text { Achillea millefolium, Agropyron } \\
\text { repens, Anthoxanthum aristatum, } \\
\text { Arrhenatherum elatius, } \\
\text { Chenopodium album, Cirsium } \\
\text { arvense, Convolvulus arvensis, } \\
\text { Dactylis glomerata, Poa trivialis }\end{array}$ \\
\hline & Maize & & $\begin{array}{l}\text { Bromus tectorum, } \\
\text { Chenopodium album, } \\
\text { Sambucus nigra, } \\
\text { Urtica dioica } \\
\end{array}$ & $\begin{array}{c}\text { Agropyron repens, Anthriscus } \\
\text { sylvestris, Arrhenatherum elatius, } \\
\text { Cirsium arvense, Dactylis } \\
\text { glomerata, Galium aparine }\end{array}$ \\
\hline & Rape & Chenopodium album & $\begin{array}{l}\text { Agropyron repens, } \\
\text { Urtica dioica, Viola } \\
\text { arvensis } \\
\end{array}$ & $\begin{array}{l}\text { Arrhenatherum elatius, Galium } \\
\text { aparine, Sambucus nigra }\end{array}$ \\
\hline
\end{tabular}



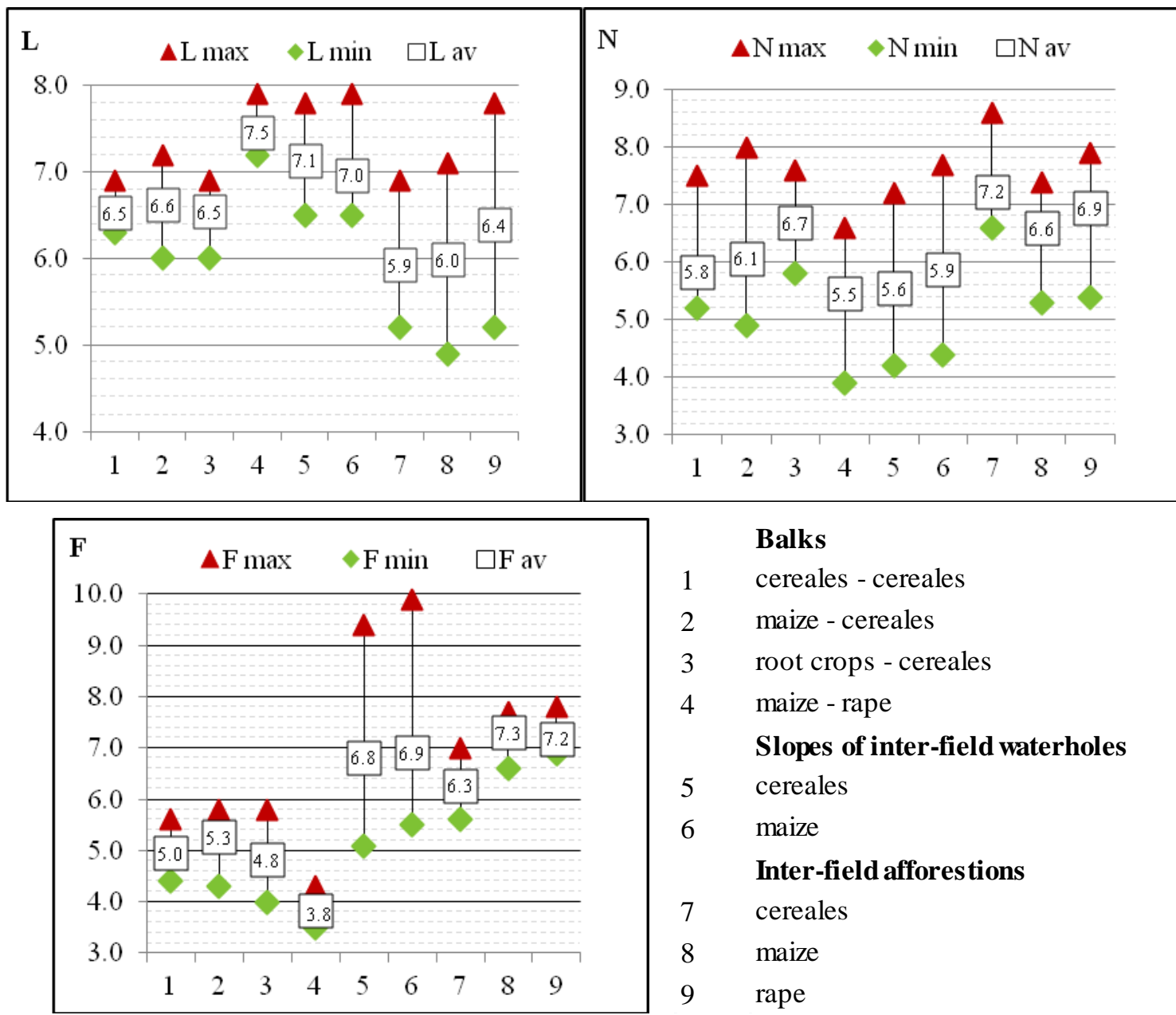

Balks

cereales - cereales

maize - cereales

root crops - cereales

maize - rape

\section{Slopes of inter-field waterholes}

cereales

maize

Inter-field affores tions

cereales

maize

rape

Figure 5. Averages and scopes of phytoindicative coefficients: L - light, F - moisture, $N$ richness of soil in nitrogen for the analyzed phytocenoses of environmental islands

Therefore, moisture was a crucial factor in differentiating the islands that were analyzed. It was most visible on the inter-field waterhole banks and least visible in the phytocenoses of inter-field balks (Fig. 6). Moreover, almost half of the variables on the chart may be explained with the gradients of trophism and insolation i.e. the habitats with high nitrogen content in soil are characteristic of afforestations and balks at root and corn tillages (the result of fertilization and/or a high amount of organic matter, which dissolutes quickly) and the $\mathrm{N}$ coefficients' values of balk habitats between cereals and of inter-field waterhole banks are lower than at a simultaneously far stronger insolation.

To sum up, habitat conditions characterizing moisture, light, trophism shape the phytosociological structure of environmental islands where species from the Stellarietea mediae class are concerned, i.e.:

- Balks among cereal tillages with a high proportion of Cenaturetalia species and low moisture.

- Inter-field waterhole banks among cereals and corn tillages, where not many segetal species were observed, were more moisturized and shadowed.

- Balks at roots and corn tillages with a greater proportion of PolygonoChenopodietalia species from and higher trophism of soil (Fig. 7). 


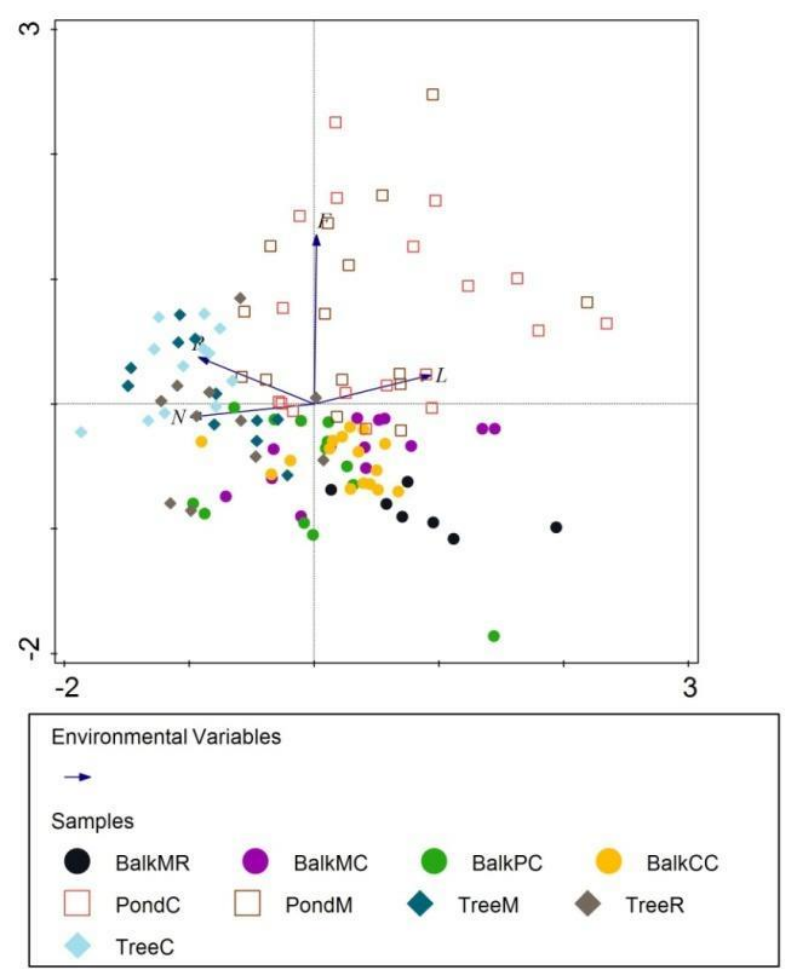

Figure 6. PCA chart of Ellenberg's phytoindicative coefficients variability within the phytosociological releves analyzed. Explanations: L - Light; $F$ - Moisture; $R$ - Soil Reaction; $N$

- Nutrient Content; BalkMR - balks between tillages of maize and rape; BalkMC - balks between tillages of maize and cereals; BalkPC - balks between tillages of root crops and grain; BalkCC - balks between tillages of cereals; PondC - slopes of inter-field waterholes among tillage of cereals; PondM - slopes of inter-field waterholes among tillages of maize; TreeM inter-field afforestations bordering the tillage of maize; TreeR - inter-field afforestations bordering the tillage of rape; TreeC - inter-field afforestations bordering the tillage of cereals

\section{Discussion}

Arable areas are terrain affected by dynamic processes and changes connected with human activity, which endangers biodiversity, including segetal and ruderal phytocenoses (Lososová and Simonová, 2008; Kleps, 2009; Meyer et al., 2010). One of the means to retain this is landscape diversification and maintenance of the highest possible fragments of natural and half-natural flora (Bożętka, 2007; Loster, 1991; Nicholas and Altieri, 2013). Erissman et al. (2016) stresses that agriculture can contribute to the increase in and conservation of biodiversity, for example, by smarter management of marginal land, but also by managing fertile areas. Floral phytocenoses formed on these special environmental islands are characterized by a large number of species whose biological spectrum are not distorted by arable cultivation conducted on the neighbouring agrocenoses. However, phytocenoses of these areas differ both in terms of the total number of species and the presence of segetal species represented by the Stellarietea mediae class. The results obtained here show that phytocenoses formed in the habitats of well moisturized inter-field waterhole banks and brushwood are the richest in floral species. Myśliwy et al. (2007) also draw attention to the fact that interfield brushwood contains numerous species, which is the result of the appearance of all the floral layers. 


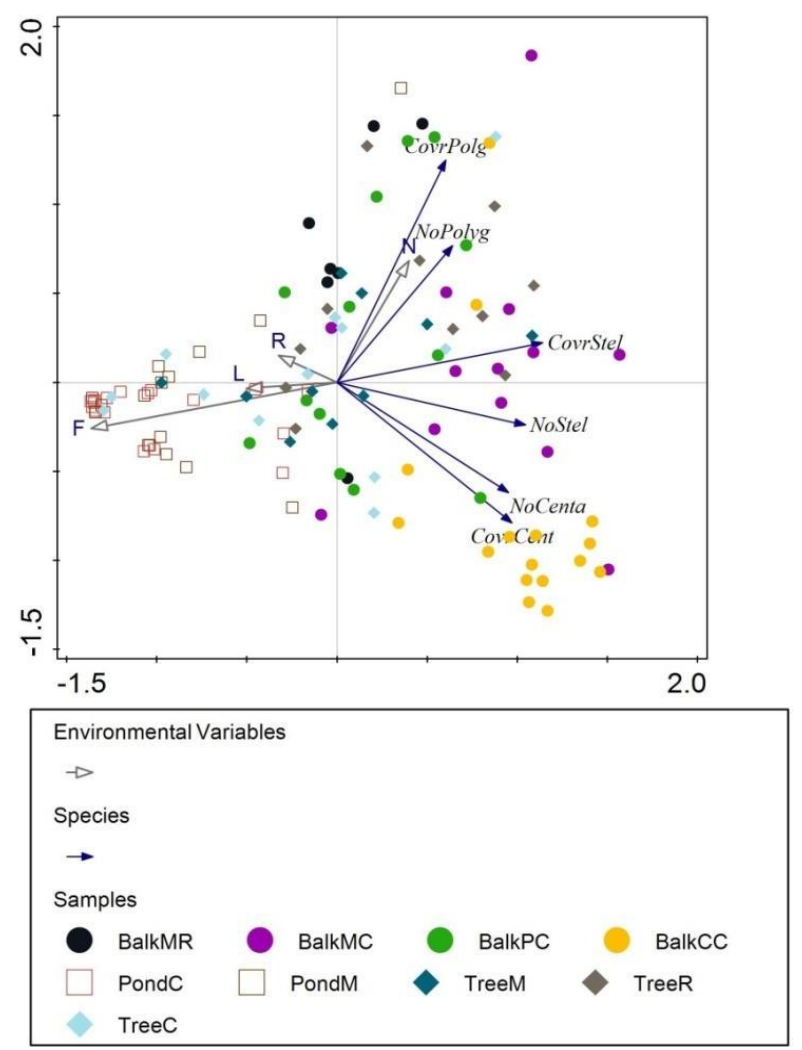

Figure 7. Ordination area representing the spread of photos between phytosociological data and habitat coefficients. Explanations: L - Light; $F$ - Moisture; $R$ - Soil Reaction; $N$ - Nutrient

Content; CoverPolg - cover by species from Polygono-Chenopodietalia Order; NoPolyg Number of species from Polygono-Chenopodietalia Order; CoverSism - cover by species from Sisymbrietalia Order; NoSism - Number of species from Sisymbrietalia Order; CoverCent cover by species from Centauretalia cyani Order; NoCent - Number of species from Centauretalia cyani Order; BalkMR - balks between tillages of maize and rape; BalkMC - balks between tillages of maize and cereals; BalkPC - balks between tillages of root crops and grain;

BalkCC - balks between tillages of cereals; PondC - slopes of inter-field waterholes among tillage of cereals; PondM - slopes of inter-field waterholes among tillages of maize; TreeM inter-field afforestations bordering the tillage of maize; TreeR - inter-field afforestations bordering the tillage of rape; TreeC - inter-field afforestations bordering the tillage of cereals

Reichholf (1998) and Ożgo (2010) claim that good light flow in changing moisturization is beneficial for fast succession processes and the colonization of banks by species from the neighbouring phytocenoses, which shapes their rich floral composition. The dependencies presented here may prove that the difference in the total number of species between the phytocenoses of environmental islands may be connected with their origin and type of habitat (Leinert, 2004).

A thorough analysis of the results, including the statistical analysis conducted with PCA and NMDS ordination methods, allows us to explain the number of segetal species from the Stellarietea mediae class observed in the phytocenoses of environmental islands from the cultivations carried out in the neighbouring fields. The type of tillage is strictly connected with soil conditions and the intensity of the agrotechnics that are conducted, which also influence the development of the accompanying species - weeds (Aoncioaie, 2012; Batáry et al., 2012; Kutyna and Malinowska, 2011). Therefore, the presence of 
fields with grain tillage positively influenced the appearance of a large proportion of species from Centauretalia cyani in the area examined, whereas in the areas attached to the root or rape tillage conducted on wheat complexes, more Polygono-Cheniopodietalia species were observed, which was also proved the results of the assessment of habitat conditions conducted using the phytoidentification method. According to these results, habitats of environmental islands neighbouring intensive root, corn or rape tillages reached higher values of the $\mathrm{N}$ coefficient at high moisturization. Moreover, Symonides (2010) and Andrzejewski (2002) highlight the particular abiotic conditions of environmental islands, which, in their opinion, may be caused by their small areas and, consequently, the impossibility of normal ecosystem processes.

The dependency between the number of segetal species on balks and the intensity of tillage was investigated by Karg (2003). According to his study, in the East of Poland, where agricultural is mostly ecological, almost 400 plant species were observed on balks and neighbouring parts of fields, whereas on balks at intensively cultivated fields in Wielkopolska, a lower number of species was found (c. 150) (Krasicka-Korczyńska and Borzych, 2002). In comparison to this data, the number of 70 plant species on the balks analyzed (including 8-27 taxons from the Stellarietea mediae class) may be considered very low and proof that the adjacent fields are intensively cultivated, especially in terms of 'weed control'. The influence of the neighborhood on the species composition of interfield afforestations was also observed, especially in the undergrowth (Pykälä et al., 2005). Jones and Haggar (1999), French and Cummins (2001) and Honnay et al. (2005) claim that the herbal layer of inter-field brushwood is often influenced by the intensity of cultivation in the adjacent areas, especially in the range of nitrogen and natural fertilization. Furthermore, Stulichowa (1979) emphasizes the impact of brushwood origins on their species composition. They may be the remains of forests or develop spontaneously. Their spontaneous development usually happens on balks, and in such conditions, in the undergrowth, segetal species from the Stellarietea mediae class are found. The results of floristic research concerning phytosociological structure of interfield brushwood phytocenoses prove their spontaneous growth on balks. The lack of occasional mowing led to their gradual bushing and the growth of trees.

Analysis of the results concerning the spectrum of live forms from the geographicalhistorical forms confirms that the phytocenoses of environmental islands are characterized by minor constancy (Myśliwy et al., 2007; Skrzyczyńska et al., 2014). Their species composition depends on the cultivation intensity of the neighbouring arable lands, which may endanger the floral variability of balks dominated by shortterm species and archaeophytes (Dobrzański and Adamczewski, 2009). In turn, the assessment of constancy levels of species observed in the research areas shows that in the arable land, flora, especially of small water tanks and their banks, is endangered. In the waterhole habitats, no species of the $5^{\text {th }}$ or $6^{\text {th }}$ constancy level was found. The great threat to the flora of small water tanks in the arable landscape is explained by Myśliwy et al. (2007) with their disappearance as a result of amelioration, among other factors.

In the era of intensity of agriculture, environmental islands have become the only place of survival to the segetal flora and especially for short-term species (Peterken and Francis, 1999). They are vulnerable due to the agrotechnical measures conducted in the adjacent agrocenoses. Nevertheless, one needs to remember that these areas are some of only very few places in the agricultural landscape where half-natural flora grows, and therefore play an important role in the maintenance of biodiversity. As a consequent, more and more programs are being launched in order to protect segetal flora (Meyer et al., 2010). 


\section{Conclusions}

1. Ecological margins are characterized by large floral diversity, which stems from:

- Cultivation of adjacent areas - the biggest species diversity was observed on environmental islands adjacent to grain tillages; it was also where the largest average number of species in the phytosociological photo was found.

- Habitat variability - the total largest species richness was observed on the inter-field waterhole banks, which was characterized by a wide spectrum of moisturization and trophism.

2. Segetal species from the Stellarietea mediae class usually expand to inter-field balks, where they reach high levels of constancy. They are also found among inter-field afforestations, albeit less frequently.

3. Inter-field balks and inter-field waterhole banks are clearly dominated by species from Centauretalia cyani among grain tillages, whereas species from PolygonoChenopodietalia predominate among corn fields.

4. In the structure of live forms, annual terophytes dominate on inter-field balks, whereas inter-field waterhole banks and inter-field afforestations are dominated by hemicrytophytes.

5. On balks and in afforestations, almost $100 \%$ of the species are synanthropic ones (mainly aprophytes and archaeophytes), and inter-field waterhole banks are dominated by native flora with a $10 \%$ share of non-synanthropic spontaneophytes.

6 . Further research on the conservation of species diversity in agricultural areas is extremely important as it allows for the selection of appropriate management tools for these areas in order to protect biodiversity as effectively as possible.

\section{REFERENCES}

[1] Afranowicz-Cieślak, R. (2011): Udział i rola antropofitów we florze zadrzewień w rolniczym krajobrazie Żuław Wiślanych. W: Kącki Z., Stefanek-Krzaczek E. [red.] Synantropizacja $\mathrm{w}$ dobie zmian różnorodności biologicznej. - Acta Botanica Silesiana 6: 157-170.

[2] Andrzejewski, R. (2002): Wyspy środowiskowe - kilka pojęć i zagadnień. - In: Banaszak, J. (ed.) Wyspy środowiskowe. Bioróżnorodność i próby typologii. Wydawnictwo Akademii Bydgoskiej, Bydgoszcz, pp. 291-302.

[3] Aoncioaie, C. (2012): Changes in the situation of segetal associations from the agrocoenosis of a previously well studied region of Romania. - Romanian Agricultural Research INCDA Fundulea 29: 379-388.

[4] Banaszak, J., Cierzeniak, T. (2002): Wyspy środowiskowe krajobrazu rolniczego. - In: Banaszak, J. (ed.) Wyspy środowiskowe. Bioróżnorodność i próby typologii. Pr. zbior. Wydaw. Ak. Bydg., Bydgoszcz, pp. 25-34.

[5] Barrios, E., Valencia, V., Jonsson, M., Brauman, A., Hairiah, K., Mortimer, P. E., Okubo, S. (2018): Contribution of trees to the conservation of biodiversity and ecosystem services in agricultural landscapes. - International Journal of Biodiversity Science, Ecosystem Services \& Management 14(1): 1-16. DOI: 10.1080/21513732.2017.1399167.

[6] Batáry, P., Fischer, J., Báldi, A., Crist, T. O., Tscharntke, T. (2011): Does habitat heterogeneity increase farmland biodiversity? - Front Ecol Environ. 9: 152-153.

[7] Batáry, P., Holzschuh, A., Orci, K. M., Samu, F., Tscharntke, T. (2012): Responses of plant, insect and spider biodiversity to local and landscape scale management intensity in cereal crops and grasslands. - Agriculture, Ecosystems \& Environment 146(1): 130-136. 
[8] Bjelajac, Z., Mijatovic, M. D., Fatic, M. Z., Dukanovic, D. (2014): Liability for biodiversity protection with special focus on wild flora and fauna conservation. - Journal of Environmental Protection and Ecology 15(1): 194-203.

[9] Bożętka, B. (2007): Wybrane problemy waloryzacji zadrzewień i zakrzaczeń obszarów rolnych. - In: Kistowski, M., Korwel-Lejkowska, B. (eds.) Waloryzacja środowiska przyrodniczego w planowaniu przestrzennym. Fundacja Rozwoju Uniwersytetu Gdańskiego, Gdańsk, pp. 117-127.

[10] Braak, C. J. F., Šmilauer, P. (2002): Canoco Reference Manual and User's Guide: Software for Ordination (Version 5.0). - Microcomputer Power, Ithaca.

[11] Chappell, M. J., LaValle, L. A. (2011): Food security and biodiversity: can we have both? An agroecological analysis. - Agriculture and Human Values 28(1): 3-26.

[12] Dąbrowska-Prot, E. (1984): Biocoenoses in an industrial landscape. - Polish Ecological Studies 10: 3-230.

[13] Dias Tavares, P., Camardelli Uzeda, M., Santos Pires, A. (2019): Biodiversity conservation in agricultural landscapes: the importance of the matrix. - Floresta Ambient. 26(4). DOI: 10.1590/2179-8087.066417.

[14] Dobrzański, A., Adamczewski, K. (2009): Wpływ walki z chwastami na bioróznorodnosć agrofitocenoz. - Progress in Plant Protection 49(3): 982-995.

[15] Duelli, P., Obrist, M. K. (2003): Regional biodiversity in an agricultural landscape: the contribution of seminatural habitat islands. - Basic and Applied Ecology 4: 129-138.

[16] Ellenberg, H., Leuschner, C. (2010): Vegetation Mitteleuropas mit den Alpen in ökologischer, dynamischer und historischer Sicht. 6. Aufl. - Eugen Ulmer, Stuttgart.

[17] Erisman, J. W., Eekeren, N., Wit, J., Koopmans, C., Cuijpers, W., Oerlemans, N., Koks, B. J. (2016): Agriculture and biodiversity: a better balance benefits both. - AIMS Agriculture and Food 1(2): 157-174 DOI: 10.3934/agrfood.2016.2.157.

[18] Fisher, J., Lindenmayer, D. B. (2007): Landscape modification and habitat fragmentation: syntehesis. - Global Ecology and Biogeography 16: 265-280.

[19] French, D. D., Cummins, R. P. (2001): Classification, composition, richness and diversity of British hedgerows. - Appl. Veg. Sci. 4: 213-228.

[20] Hill, M. O. (1979): TWINSPAN - a FORTRAN Program for Arranging Multivariate Data in an Ordered Two-Way Table by Classification of the Individuals and Attributes. Section of Ecology and Systematics, Cornell University, New York.

[21] Hennekens, S. M., Schaminée, J. H. J. (2001): TURBOVEG, a comprehensive data base management system for vegetation data. - Journal of Vegetation Science 12: 589-591.

[22] Honnay, O., Jacquemyn, H., Bossuyt, B., Hermy, M. (2005): Forest fragmentation effects on patch occupancy and population viability of herbaceous plant species (Tansley review). - New Phytologist 165(5): 1-14.

[23] Jackowiak, W. (1990): Antropogeniczne przemiany flory roślin naczyniowych Poznania. - Wyd. Nauk. UAM 42: 1-242.

[24] Jacot, K., Eggenschwiler, L., Junge, X., Luka, H., Bosshard, A. (2006): Improved field margins for a higher biodiversity in agricultural landscape. - Aspects Appl Biol. 81: 1277.

[25] Jones, D., Haggar, R. J. (1999): Impact of nitrogen and organic manures on yield botanical composition and herbage quality of two contrasting field margins. - Biol. Agric. Hortic. 14: 107-123.

[26] Kapeluszny, J., Haliniarz, M. (2010): Ekspansywne i zagrozone gatunki flory segetalnej w środkowo-wschodniej Polski. - Annales Universitatis Mariae Curie-Skłodowska Lublin-Polonia, Sectio E 65(1): 26-33.

[27] Karg, J. (2003): Zadrzewienia śródpolne, strefy buforowe i miedze. - Biblioteczka Krajowego Programu Rolnośrodowiskowego, MRiRW, Warszawa.

[28] Kindt, R., Coe, R. (2005): Three Diversity Analysis. A Manual and Software for Common Statistical Methods for Ecological and Biodiversity Studies. - World Agroforestry Centre (ICRAF), Nairobi. 
[29] Kleps, C. (2009): Sustainable agriculture - the sole alternative for the present environmental and climatic constrains. - Journal of Environmental Protection and Ecology 10(4): 1187-1193.

[30] Knapp M., Řezáč M (2015): Even the smallest non-crop habitat islands could be beneficial: distribution of carabid beetles and spiders in agricultural landscape. - PLoS ONE 10(4): e0123052. https://doi.org/10.1371/journal.pone.0123052.

[31] Krasicka-Korczyńska, E., Borzych, W. (2002): Rośliny lecznicze wysp środowiskowych w krajobrazie rolniczym na przykładzie gminy Kcynia. - In: Banaszak, L. J. (ed.) Wyspy środowiskowe. Bioróżnorodność i próby typologii. Wyd. ABydg., Bydgoszcz, pp. 25-34.

[32] Kutyna, I., Malinowska, K. (2011): Struktura geograficzno-historyczna flory zbiorowisk upraw zbóż ozimych i kilkunastoletnich odłogów. Folia Pomeranae Universitatis Technologiae Stetinensis. - Agricultura, Alimentaria, Piscaria et Zootechnica 17: 31-39.

[33] Lienert, J. (2004): Habitat fragmentation effects on fitness of plant populations - a review. - Journal for Nature Conservation 12: 53-72.

[34] Lososová, Z., Simonová, D. (2008): Changes during the $20^{\text {th }}$ century in species composition of synanthropic vegetation in Moravia (Czech Republic). - Preslia 80: 291305.

[35] Loster, S. (1991): Różnorodność florystyczna w krajobrazie rolniczym i znaczenie dla niej naturalnych i półnaturalnych zbiorowisk wyspowych. - Fragm. Flor. Geobot. 36(2): 427-457.

[36] Magurran, A. (1996): Ecological Diversity and Its Measurement. - Blackwell Publishing, Malden.

[37] Matuszkiewicz, W. (2012): Przewodnik do oznaczania zbiorowisk roślinnych Polski. Wyd. naukowe PWN, Warsaw.

[38] Meyer, S., Wesche, K., Leuschner C., van Elsen, T., Metzner, J. (2010): A new conservation strategy for arable plant vegetation in Germany - the project " 100 fields for biodiversity". - Plant Breeding and Seed Science 61: 25-34.

[39] Morelli, F. (2013): Relative importance of marginal vegetation (shrubs, hedgerows, isolated trees) surrogate of HNV farmland for bird species distribution in Central Italy. Ecol. Eng. 57: 261-266.

[40] Myśliwy, M., Ciaciura, M., Umiastowska, M. (2007): Siedlsika marginalne źródliskowego odcinka doliny Płoni ostoją chronionych, rzadkich i zagrożonych gatunków roślin naczyniowych. Zeszyty Naukowe Uniwersytetu Szczecińskiego. - Acta Biologica 14: 163-183.

[41] Nicholls, C. I., Altieri, M. A. (2013): Plant biodiversity enhances bees and other insect pollinators in agroecosystems. A review. - Agronomy for Sustainable Development 33(2): 257-274.

[42] Ożgo, M. (2010): Rola małych zbiorników wodnych w ochronie bioróżnorodności. Parki Narodowe i Rezerwaty Przyrody 29(3): 117-124.

[43] Pykälä, J., Luoto, M., Heikkinen, R., Kontula, T. (2005): Plant species richness and persistence of rare plants in abandoned semi-natural grasslands in northern Europe. Basic Appl. Ecol. 6: 25-33.

[44] Peterken, G. F., Francis, J. L. (1999): Open spacer as habitats for vascular Grodnu flora species in the woods of central Lincolnshire, UK. - Biol. Conserv. 91: 55-72.

[45] Reichholf, J. (1998): Tereny wilgotne (leksykon przyrodniczy). - GeoCenter, Warszawa.

[46] Skrzyczyńska, J., Stachowicz, P., Rzymowska, Z., Skrajna, T. (2014): Floristic variation in communities of fallow lands of the Podlaski Przełom Bugu mesoregion depending on the time of removal of fields from cultivation. - Acta Agrobotanica 67(1): 99-108.

[47] Stulichowa, B. (1979): Roślinnosć miedz i zadrzewień śródpolnych pasma Policy w Karpatach Zachodnich. - Fragm. Flor. et Geobot. 25(1): 113-122.

[48] Symonides, E. (2010): Znaczenie powiązań ekologicznych w krajobrazie rolniczym. Woda-Środowisko-Obszary Wiejskie 10(4): 249-263. 
[49] Tscharntke, T., Steffan-Dewenter, I., Kruess, A., Thies, C. (2002): Contribution of small habitat fragments to conservation of insect communities of grassland-cropland landscapes. - Ecological Applications 12(2): 354-363.

[50] Tichy, L. (2002): JUICE, software for vegetation classification. - Journal of Vegetation Science 13: 451-453.

[51] Tokarska-Guzik, B., Dajdok, Z., Zając, M., Urbisz, A., Danielewicz, W. (2011): Identyfikacja i kategoryzacja roślin obcego pochodzenia jako podstawa działań praktycznych. W: Kącki, Z., Stefańska-Krzaczek, E. [red], Synantropizacja w dobie zmian różnorodności biologicznej. - Acta Botanica Silesiaca 6: 23-53.

[52] Zarzycki, K., Trzcińska-Tacik, H., Różański, W., Szeląg, W., Wołek, J., Korzeniak, U. (2002): Ecological Indicator Values of Vascular Plants of Poland (Ekologiczne liczby wskaźnikowe roślin naczyniowych Polski). - Wyd. PAN, Kraków.

\section{APPENDIX}

Figure A1. Balks
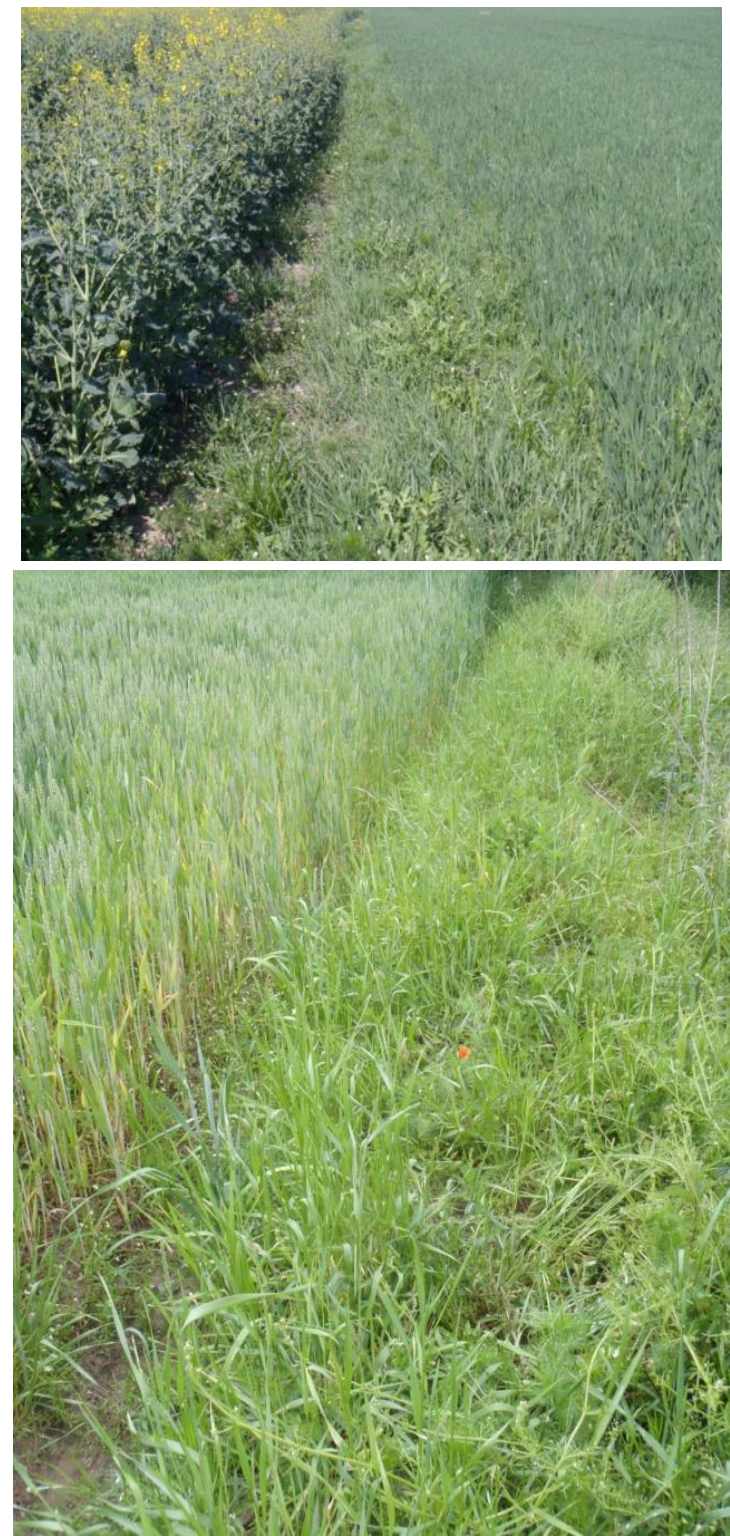

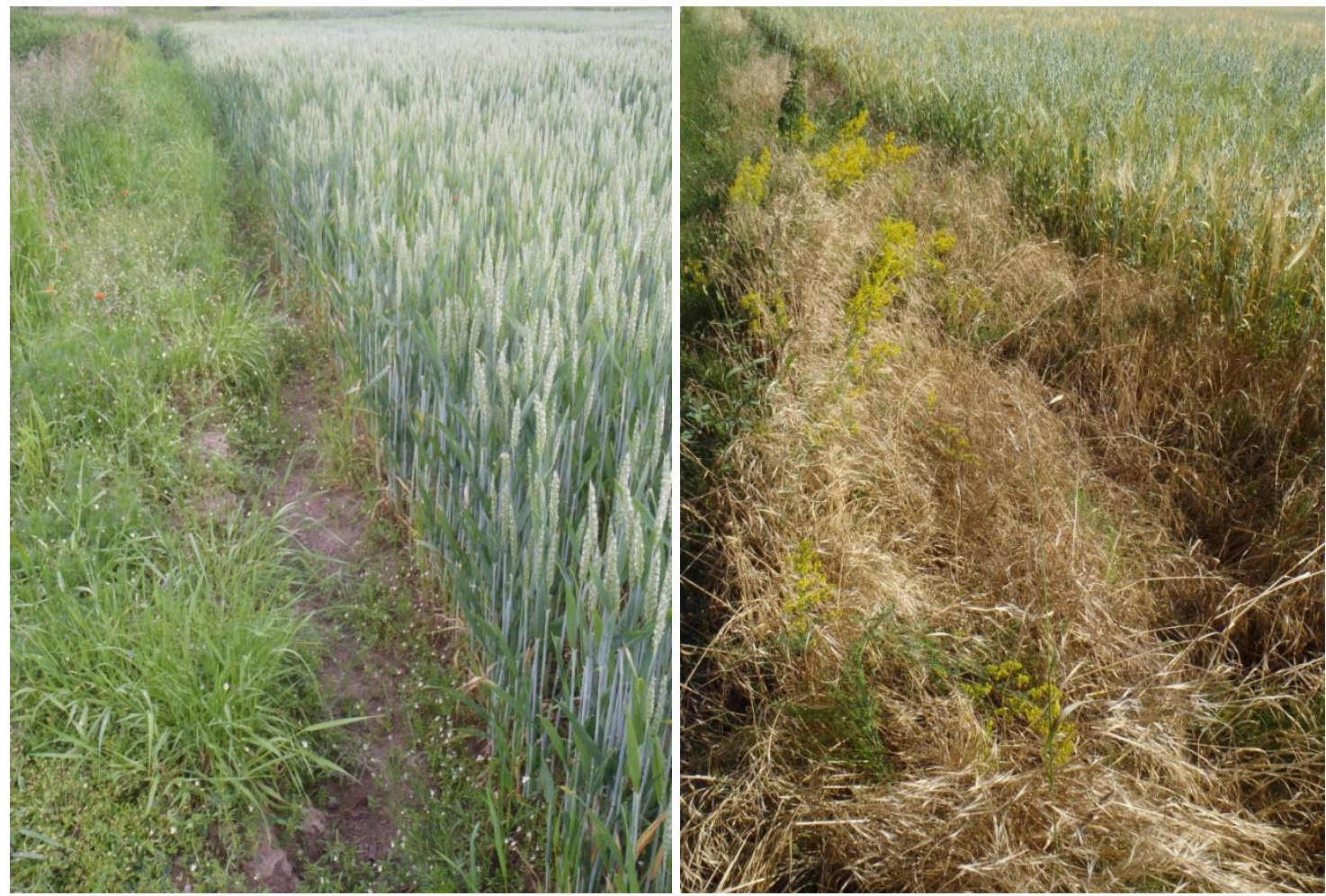

Figure A2. Slopes of inter-field waterholes
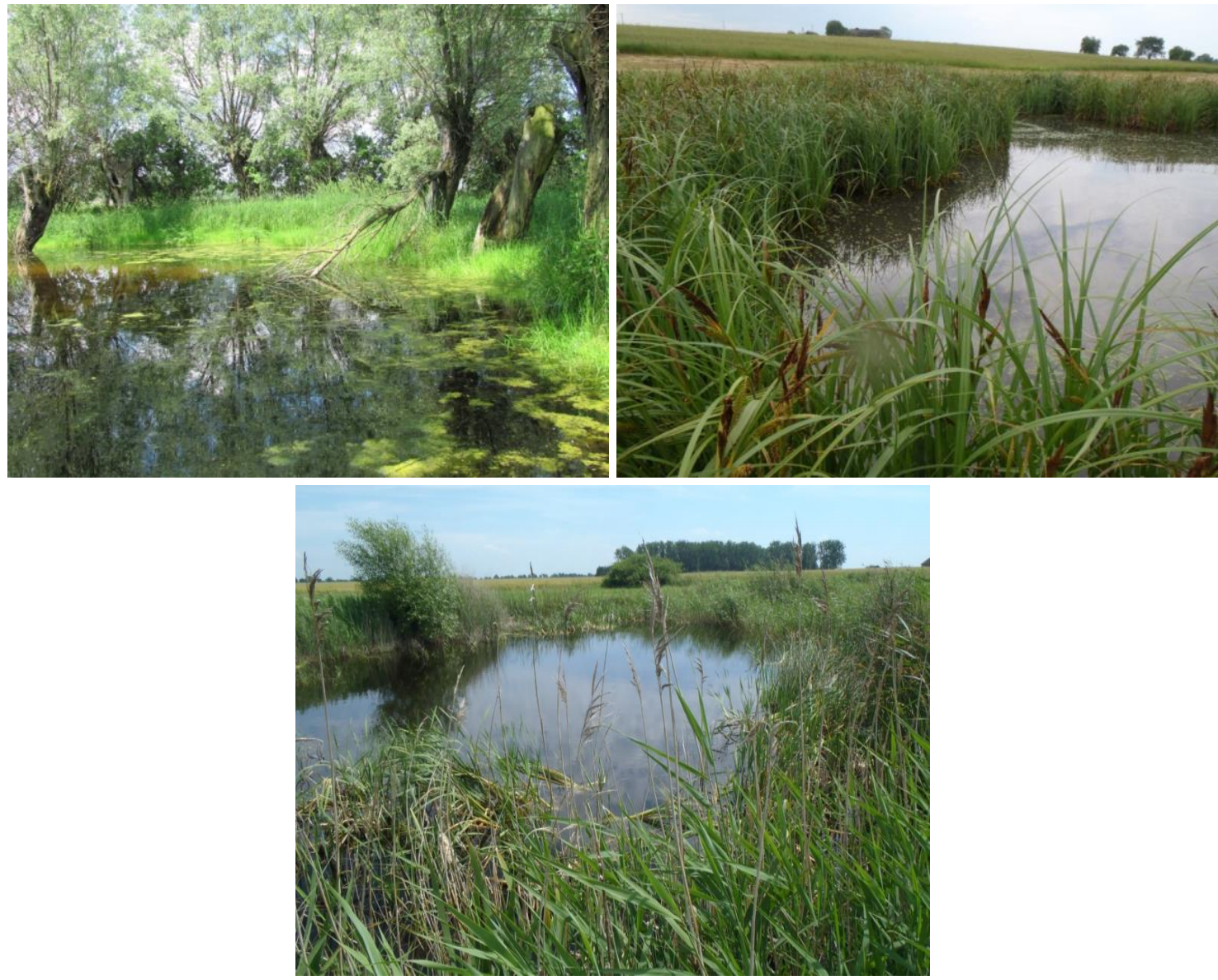

APPLIED ECOLOGY AND ENVIRONMENTAL RESEARCH 18(3): 4223-4240.

http://www.aloki.hu • ISSN 15891623 (Print) • ISSN 17850037 (Online)

DOI: http://dx.doi.org/10.15666/aeer/1803_42234240

(c) 2020, ALÖKI Kft., Budapest, Hungary 
Figure A3. Inter-field afforestations

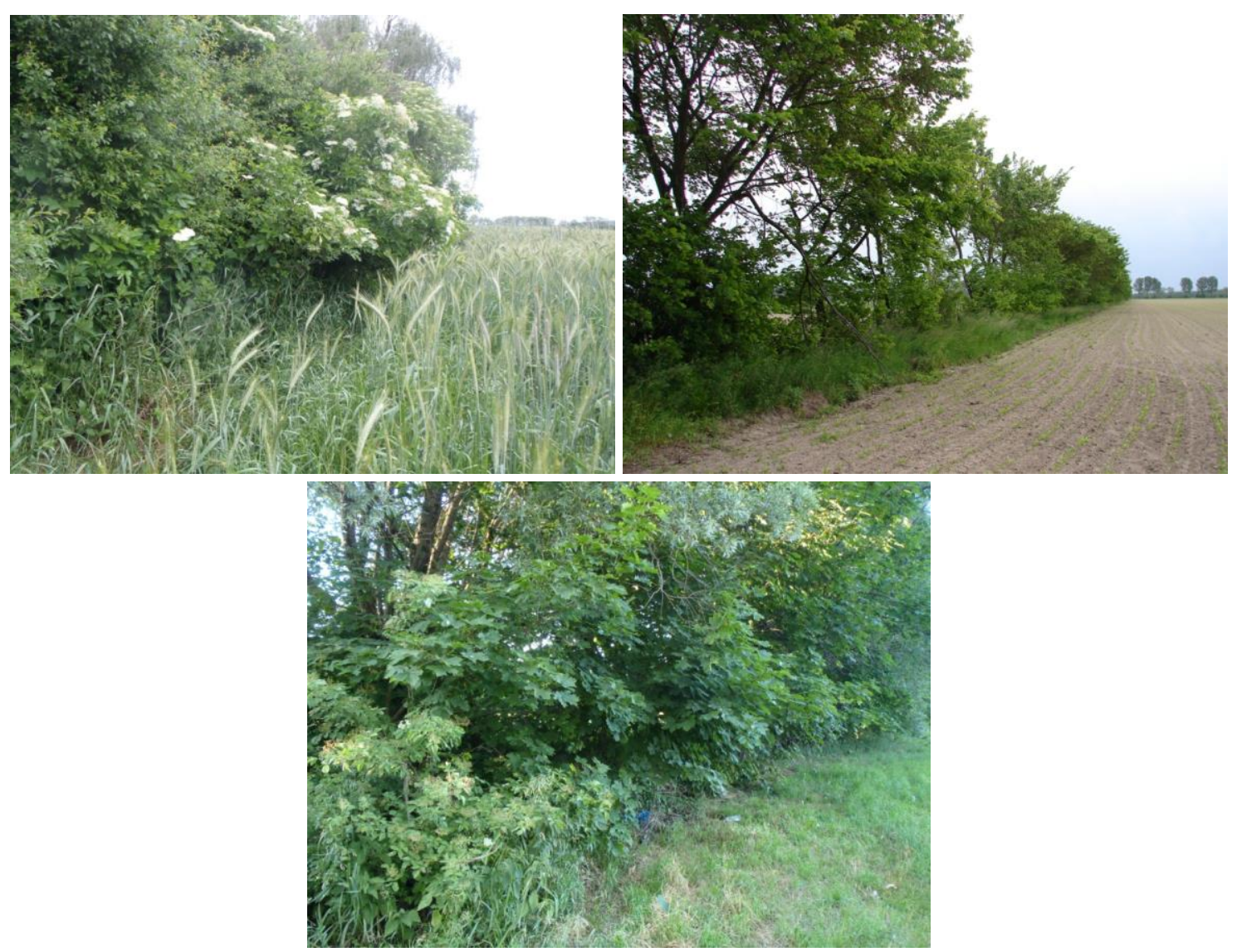

APPLIED ECOLOGY AND ENVIRONMENTAL RESEARCH 18(3): 4223-4240.

http://www.aloki.hu • ISSN 15891623 (Print) • ISSN 17850037 (Online)

DOI: http://dx.doi.org/10.15666/aeer/1803_42234240

(c) 2020, ALÖKI Kft., Budapest, Hungary 